\title{
The Presentation of the Gentleman in Jane Austen's Novel Emma
}

\section{(1816)}

\author{
Ala Eddin Sadeq ${ }^{1}$ \\ ${ }^{1}$ Department of English Language, Literature and Translation, Zarqa University, Zarqa, Jordan \\ Correspondence: Ala Eddin Sadeq. E-mail: alaeddin_english@zu.edu.jo, Alaeddin71@yahoo.com.
}

Received: May 18, 2017

Accepted: May 25, 2017

Online Published: June 23, 2017

doi:10.5539/ass.v13n7p181

URL: https://doi.org/10.5539/ass.v13n7p181

This research is funded by the Deanship of Scientific Research at Zarqa University-Jordan.

\begin{abstract}
The aim of this study is to trace the origin of the concept of "gentility" and its development over the course of time. The meaning of the word has shifted slightly since its original use in the classification system. During the Industrial Revolution, the meaning of the word "gentleman" expanded to include the merchants, clergy, army officers, and parliamentary members. The mercantile elites were referred as gentlemen due to the wealth and influence that they had amassed. The text selected for analysis is Jane Austen's Emma (1816), which highlights the themes of social classes. The novel presents characters that belong to different classes, and sheds light on ideas such as the superiority of the upper-class over the middle and low-class people, and the attempts that people make to climb to higher classes in the society.
\end{abstract}

Keywords: gentility, Emma, Jane Austen, social classes

\section{Introduction}

A gentleman is defined as a man of good and courteous character. The female equivalent is called a lady. The major determinants of a gentleman are his values, moral standards, and honor. The man in question should dedicate all his activities to high standards of behavior while at the same time avoiding the feeling that he is better than others. A gentleman's set of principles constitutes politeness, calmness, being considerate at all times, and performing quality work. These values are considered the cornerstone of the modern-day gentleman (Essays, 2016). In the modern context, the word gentleman refers to a man of courtesy and good behavior. It originated from the English classification system where it was used to refer to men of the lowest rank in the gentry. The gentry was placed below the esquires and above the yeomen. They were the youngest sons of the younger sons of peers as well as the baronets, knights, and esquires. The word, therefore, denoted the state of being gentle that the peers and the gentry were known for (Girouard, 1981, p. 100).

When the word gentleman is used, the most common discernment among individuals is the act of being gallant and chivalrous towards women. This is accurate because a gentleman should be respectful towards women. He should pay attention to the needs and wants of a woman while at the same time understanding his value and purpose and resisting deviating from them. The gentleman, while taking a female out, should choose a place where the lady feels comfortable in. He puts his point across through logic and understanding. He also performs his responsibilities towards all people; be it family or friends. He never breaks his word, thus it is his desire to fulfill all the promises that he has ever made. Finally, a gentleman should be in constant search for knowledge to be vested with the different subjects (Cody, 2004).

In the early nineteenth century, the meaning of gentility had shifted from the original birthright classification system to take a different tone of an evangelical gentleman that was identified through his values and manners. The family evangelical gentleman was a profound and deeply religious family man who was influenced by the evangelical reform. The society's main aim was restructuring attitudes and behaviors from the corruption of the aristocracy during the regency that occurred in 1795 to 1837 . This aristocracy was comprised of freedom, elegance, and extravagance (Girouard, 1981, p. 225). These were the values that evangelists aimed at eradicating through the introduction of a newer set of standards that leaned towards religion. They focused on sincerity and earnestness while urging the people to be moral, chaste, and be more charitable so as to avoid the disreputable 
behavior of the Restoration rakes that was characterized by egotism, playfulness, and self-importance. A sincere appearance was like conduct that could be clear as a noticeable manifestation of a well-ordered and morally consistent inner self (Greenblatt, 2012, p. 118). In the mid-nineteenth century, there was an emphasis on the muscular Christian gentleman whereby boys were encouraged to engage in sports such as rugby and soccer and leave behind subjects like humanities that were seen as feminine and childish. The gentleman had to use sports to develop manly characteristics of hardiness, self-control, and endurance. The etiquette books that were used to create refined gentlemen were replaced with tough builders of empires and adventure-oriented individuals. The common characteristic among these gentlemen was romantic at heart, chivalry, and moral conduct. Thus, they were deemed as morally superior and modeled to take leadership positions (McMaster \& Copeland, 1997, p. 180).

The Industrial Revolution brought about a new meaning to gentility. The middle-class was rapidly rising, and they desired to make themselves gentlemen by virtue of the wealth they had amassed. Industrialization had spread quickly leading to a rise of landowners and industrial experts. Intermarriage had occurred between the social classes and people could acquire land through purchasing rather than inheritance. The new middle-class gentleman had a desire to learn manners that made one become a gentleman, in the same way, they purchased stylish homes, refined clothes, and domestic assets. The market in the mid- $19^{\text {th }}$ century was flooded with etiquette books that taught the rules of polite society (Rubinstein, 1993, pp. 102-139). Thus, a gentleman was defined through the wealth, refinement, intelligence, and social control that they possessed while at the same time being devoid of class implications.

Any man could aspire to be called a gentleman if they adhere to the expected code of conduct. The distinct features of gentlemen were: position, education, and manners. Such acquired-qualities can make a self-made gentleman who replaced the man of noble birth and chosen family. This new gentleman adhered to honor, charity, and social responsibility. Gentility was an object of humor to Oscar Wilde who pointed out the nature of the upper class as full of hypocrisy through their strict superficial manners. He urged people to follow a life of pleasure calling out marriage as boring. The reputation of gentlemen was tarnished with accounts of criminal behavior, prostitution, and homosexuality that was then considered unacceptable (Losey \& Brewe, 2000, p. 313). The gentility class was not privileged over science and technology as successful businessmen from the fields that were previously considered ungentlemanly such as trade and industry assumed political leadership. The society shifted towards an urban context whereby the commercial elite changed the society's dynamics (Rubinstein, 1993, p. 70).

This study is theoretical and analytical. It is based on the previous studies that were carried out concerning the concept of gentility and Jane Austen's Emma (1816). This study seeks to identify gentility and the changes of its meaning and interpretation among various ages of human development. Scholars had in-depth explanations of the origin of gentility, the changes that the term has undergone through the $19^{\text {th }}$ century, the industrial revolution, and the modern-day meaning.

In 1950, David Thomson explores gentility and what it meant in the Victorian age. He argues that the period was characterized by strenuous activity and rapid changes in the basic ideas of the society. It was also a time of many inventions and expansion in England. He asserts that the early industrialization in England was the cause of social and economic setbacks that resulted in moral decadence. The ranking system had special meaning among people because it came with social esteem (Kirkland \& Thompson, 1999, p. 50). The position of a gentleman fascinated many people because they could share in the prestige of the gentry that had existed earlier in the aristocracy. People could penetrate this rank from below so with property rights they made their rise to aristocracy a reality. He focuses on how people fixed themselves into aristocracy and thus were called self-made gentlemen. (Gilmour, 1981, p. 5) He also evaluates what it meant to be a gentleman by birthright, and designates the groups that belong to this category: noblemen, clergymen, parliamentarians, and army officers. He, however, notes that an actual gentleman needed more than birthright. The other quality emphasized is being of a good moral standing which involved qualities, such as sympathy, gentleness, and a fine nature. Charles Dickens, for instance, highlights the life of the people of the lower middle-class in his novel Great Expectations. He puts out his perspective through the protagonist, Pip, who desires to be a gentleman by gaining respect and being less common (Dickens, 1989, p. 60). Thackeray and Trollope focus on the higher middle class in their exploration of gentility. They point out the basis of gentility because of the questionable dignity of work that undermined the pillars that gentility is built on. They discuss the disillusionment that exists among the people as they struggle to redefine themselves in a rapidly changing society (Norton, 1993, p. 105). 


\subsection{Objectives Methodology}

One of the objectives of this study is to uncover the meaning of the word gentility. The term has been used in the modern-day with its meaning geared towards how men treat or should treat women. The Oxford dictionary defines gentility accurately whereby it points out to the character. This shows that its meaning incorporates much more than how to relate to women. This study also investigates the evolution of the meaning of the term gentlemen over time. It reveals that the meaning has shifted from the original gentry towards a more relaxed reference in the Victorian era. Its meaning shifted to referring to men of high religious inclination.

The moral conduct of these individuals was high. During this era, the masculine religious gentleman emerged. The Industrial Revolution changed the composition of the gentility class to include self-made gentlemen. In the modern world, gentlemen are men of chivalry and grand character and mannerisms.

The selected text for analysis is Jane Austen's Emma. The main character gradually becomes aware of herself and the people around her. The world Emma Woodhouse grew up in was a village called Highbury where her family was the most important. Emma believes that she is superior to all people in the village including her friend Harriet. Her pride poses many limitations to her, such as the lack of sympathy; a quality she acquires because of her society which has prioritized class discrimination. The novel reveals how Middle-class people strive to climb to the upper-class through marriage. It also unfolds that community membership works in each person's life. The servants are abandoned by the gentry and the two do not communicate as equals. Also, the people of the higher classes can visit the poor as seen when Emma visits the Cottagers to give the soup and also drops by the Martin family. This social class determined the roles of each member of Highbury. The text puts into perspective the classification system and the application of the initial gentry class and how people changed gradually until the system was dissolved.

\section{Discussion}

The concept of the gentleman is complicated because it touches on the Victorian patterns of thought and behavior. Many of the people in the Victorian era wanted to be called gentlemen, but there was no clear definition of what it was or how long it took to be called one. The following are the characteristics of a gentleman that are put in context through explanations from Jane Austen's Emma.

A gentleman in the early times was an individual of noble birth. Individuals of the aristocracy were gentlemen by right of birth. There was also emphasis that birth alone did not make one a full gentleman, but those who were highborn had more right to the title than the self-made gentlemen. The Victorians argued that a true gentleman should be able to survive without toil while at the same time; he should not survive off other people's toil (Keen, 2002, p. 109). Through such a perspective, the concept of gentility was a social class phenomenon. In the novel, this is illustrated by individuals such as the Woodhouses and Knightley. The Bates had been born in the upper class but lost all their wealth. They were still associated with the upper class as they received gifts from them. Thus, Jane Bates was considered of upper-class because of her birth, refinement, and achievements. The upper-class had a right to visit the lower class whenever they deemed necessary such as when offering donations, but the lower class could only visit the upper class if invited.

Gentlemen had to be wealthy. This explains why the new industrial and mercantile elites rose to the gentry by their accumulated wealth and influence. The highborn had family wealth and could live luxuriously without having to labor. George Knightley owned a lot of property such as extensive grounds and farms. He had inherited some of this property thus he was regarded as a true-born gentleman. Other high-born individuals in the novel also owned extensive pieces of land and servants. For example, Emma says that,

by next harvest, I shall be living at Hartfield, but I assure you all I shall be farming my estate, and looking after you all. There will be stability. There will be continuation though my life is to change (...) (Austen, 1816, 1993, p. 151).

The true gentlemen were expected to be able to survive without toil and labor, meaning that they were required to have enough wealth.

Ethical values are another quality of acting with gentility. It was ambiguous and difficult for people of the Victorian era to define what moral and ethical values were, but this became easier upon the introduction of chivalry. Sir Walter Scott was a great writer who described ethical values expected of a gentleman in his Waverley novels (Scott, 1998, p. 5). John Ruskin similarly wrote that a gentleman was of pure genes and perfect breeding. They were not allowed to live off other people's sweat. This was contradictory because many gentlemen lived off the labor of peasants (Ruskin \& Crowell, 1910, p. 26). In the novel, Rev. Elton is an example of a person that lacked ethical values when he married Augusta only because of her father's wealth. Augusta 
shows off her new position through her father's business wealth by calling the nobles by family names as well as wanting to be associated with them. She also insults people of the lower class showing that true class cannot be bought. She lacks basic decorum and elegance thus becomes proof that real gentility could not be attained by wealth only. Frank also fails to meet this quality when he is willing to conduct a secret engagement to Jane. This is because he deceives the people around him thus lacking in honesty and integrity which are the characteristics of true gentility. The Coles were of true character and had the right attitude because they did not pretend or exaggerate their abilities. This is seen when Mrs. Coles accepted that members of her family did not know how to play the grand piano that they had recently acquired. They were also considerate when they purchased a folding screen so that Mr. Woodhouse would feel comfortable while visiting their home (p.191)

Refined manners are another quality of a gentleman. Manners are a very crucial element of the Highbury community as people try to live up to the expected conduct of a gentleman because visitors are welcomed politely (Keen, 2002, p. 20). We see this when Jane, Frank, and Mrs. Elton are treated kind when they come to the village even though Emma and Mrs. Weston have negative perspective towards Mrs. Elton. People tolerated the faults of others, for example, the chatty nature of Miss Bates, the hypochondria of Mr. Woodhouse, and Emma's snobbishness. Members are required to be civil towards one another such that Emma insults Miss Bates at Box Hill; Knightley informs her of the bad conduct, and she takes steps towards correcting it. Some community members make it their duty to ignore insults so that they can uphold the community wellbeing. For example when the Martins are kind to Harriet despite her arrogance towards them when she rejected getting married to Robert Martin saying that he was a mere farmer.

Gentle individuals should also possess a polite discourse. This value is depicted when gentlemen treat other people in a respectful way without showing off or taking advantage. Thus, they do not force people to do things that they do not wish to do. Politeness is one of the constituents of a superior social standard that these people should possess. They portray self-respect and intellectual refinement which is eminent in their unrepressed yet fragile manners (Keen, 2002, p. 25).

People of true gentility should observe etiquette. They were required to learn basic rules for relating to other people, for instance, one should not be too demanding when being hosted by another family. Emma lacked this quality and Knightley was quick to point out to her that she lacked it when she insulted Miss Bates. She also despised people of the lower class but came to learn that Coles' family that she hated was courteous and kind.

Good education is also an indicator of gentility. Victorian individuals asserted that gentlemen were people who were educated in liberal arts that were based in Latin in a public school such as Eton, Harrow, and Rugby. The origins of such an individual would matter less, and through education, one automatically became a gentleman (Keen, 2002, p. 30). In Emma, Frank is a well-educated individual that had been adopted into a wealthy family thus gaining an upper-class status quo.

Jane Austen's Emma portrays gentility in several ways. Emma is a daughter of Woodhouse that is a wealthy family in the village of Highbury. She has great family connections, has large income that is not reliant on labor, owns the property, and is highly ranked because her only social peer is Knightley, the highest ranked gentleman in the village. She is the central character in this story. Her most eminent character traits are good-looking physique, high-spirited demeanor, intelligence, and spoiled by her father. She is the mistress of her family because her mother died when Emma was young and her elder sister had been married. She, therefore, belongs to the genteel class by birth. She portrays values that are expected of people in this class by showing compassion to the poor such as donating soup to the Martins. She shows support and love to her father despite his valetudinarian mannerisms (Keen, 2002, p. 430). However, she fails the test of true gentility because she is a strong supporter of the class system and despises the people of the lower ranks. She makes many mistakes because she believes she is always right. It is her conviction that she is the most superior person in the area and fails to act the part through her inferior manners. She ridicules Mr. Knightley for not riding his carriage and opting to walk as well as mingling with farmers. She expected him to flaunt his superiority and avoid modesty (Academic Brooklyn, 2009). The mistakes she makes that are not expected of the gentry include prejudiced mistakes such as when she exercises her powers, she misjudges that Rev. Philip Elton liked Harriet Smith, Frank Churchill liked her rather than Jane Fairfax; Harriet liked Frank rather than John Knightley, and Knightley liked Harriet instead of her. She takes pleasure in making matches for other people in the village while at the same time being a snob who cannot accept people based on their kindness and mannerisms. Juliet McMaster states,

Emma is one who specializes in social discrimination and makes prompt though often inaccurate judgments about the social station of the people around her (1997, p. 118).

The novel follows Emma as she journeys towards achieving the qualities of the true gentry in her character that 
match her high rank in the society. She grows in awareness of herself and the people around her as time progresses. Her lack of experience makes her vulnerable to making mistakes because she has only lived in Highbury under the shelter of her protective father. She has a hard task of breaking free from the restrictions that her pride has placed upon her, the perception her father has given her of herself, and the inadequate and unreliable perspective of Highbury. She needs to do all this without neglecting her intelligence, self-worth, her family, and her society (McMaster \& Copeland, 1997, p. 159). In the quest for true gentility, Emma learns that the Coles, whom she despised so much because of their low social position, were people of good moral conduct due to their kindness and courtesy. The presence of Mr. Knightley gives Emma a person to look up to as the measure of maturity that she struggles to attain. This is because he was the only person that surpassed her in social class ranking thus he could offer her some guidance. Emma is quoted saying "Mr. Knightley loves to find fault with me, you know," and Mr. Knightley says "Emma knows I never flatter her." Mr. Knightley goes on to correct Emma after the Box Hill incident when she was rude to Miss Bates. He says, "This is not pleasant to you, Emma-and it is very far from pleasant to me; but I must, I will-I tell you the truths while I can..." The problems that had been caused by wrong class perceptions are overcome when everyone corrects their character and takes up their rightful places in the social hierarchy.

Jane Austen portrays a gentleman as an individual that respects his or her position in the society by acting with a superior standard. The picture that she paints is a realistic society where characters form relationships and interactions in the societal context. She passes the message that gradations in social stratification play a crucial role in the proper and orderly functioning of the society. She had expectations that her reader would be more sensitive towards the social stratification thus she created characters that had an obsession and awareness of social classes. She shows the pretenses that exist among the high class that is termed as gentlemen as they try to ascertain their position in the society. This is shown through the existence of all kinds of people belonging to different social ranks in the society of Highbury (Academic Brooklyn, 2009). They include the phony aristocratic Churchill, legislative body of the gentry class, the affluent class, a lawyer, the apothecary Mr. Perry, the tenant farmer Robert Martin, the gypsies, servants, poor families such as the Clarks, and the land workers. Austen also points out that individuals could rise from the lower classes to become gentry. Examples from the novel include the Weston and the Coles who were initially traders.

The Coles, who "were of low origin, in trade, and only moderately genteel" (Austen, 1816, 1993, p. 190). (Whose point of view is being expressed in the quotation, Emma's and/or the narrator's?) With the increase of their income, the Coles changed their lifestyle to imitate the classes above them; they employed more servants, enlarged their house, and gave dinner parties to which they invited the "regular and best families (Austen, 1816, 1993, p. 190)

The opposite is also true, whereby wealth can be depleted and the people that were once rich find themselves among the poor. For example, when Ford visits Jane at the Bateses the narrator points out the changed conditions,

The appearance of the little sitting-room as they entered, was tranquility itself; Mrs. Bates, deprived of her usual employment, slumbering on one side of the fire, Frank Churchill, at a table near her, most deadly occupied about her spectacles, and Jane Fairfax, standing with her back to them, intent on her pianoforte (Austen, 1816, 1993, p. 153)

Austen's views are expressed when she says that Highbury tolerated the intermixing of classes as compared to London because The Highbury Whist Club comprised of gentlemen and half-gentlemen (p. 182) The point put across is that peace and happiness come from being acquainted with and accepting class distinctions. Her writing clearly shows the distinction between the rich and the poor in the society. For instance, the poor people are not able to cater for their basic needs such that they steal hens from the rich. In the text Mr. Woodhouse complains that he has lost "six good hens" while the rich are eating, dancing, celebrating, and drinking at Weston's wedding party (Austen, 1816, 1993, p. 71). In addition, the picture is painted of the poverty that existed to those who were not gentlewomen or men as Mr. Woodhouse's carriage moves across the city "Past a couple of ramshackle cottages of extraordinary squalor, a couple of ragged barefoot children have come out to gawp at them" (p.79).

The author clearly marks the contrast that existed between the Woodhouses' social class that was more superior, their gentle conduct, and nobleness and the inferior social position of the poor villagers. The gentry is her major focus during the writing of the novel. The working class and servants are merely mentioned as part of the décor and they lack any form of recognition. Even Emma and Knightley's wedding is criticized by Mrs. Elton in such a way that shows it was not up to standard.

The wedding was very much like other weddings, where the parties have no taste for finery or parade (...)" 
p. 313) (...) and Mrs. Elton, from the particulars detailed by her husband, thought it all extremely shabby, and very inferior to her own."Very little white satin, very few lace veils; a most pitiful business! Selina would stare when she heard of it. - But in spite of these deficiencies, the wishes, the hopes, the confidence, the predictions of the small band of true friends who witnessed the ceremony, were fully answered in the perfect happiness of the union (Austen, 1816, 1993, p. 313).

Austen uses the narrator's voice to show irony of class distinctions when the most noble individuals could not pull off a grand ceremony. It was easy for Weston to point out the different things that were not right with the wedding and thus gossip about it. There were specific clothes and accessories that people were supposed to dress in on such occasions so that they could resonate with the societal expectations. This shows the social distinction that existed in the society when Jane Austen wrote the novel. The refined and civilized etiquette of the members of the high society is put into question by the author when she shows that they gossip (Mullan, 2012). Mrs. Elton criticized Emma's wedding by pointing out what was lacking. She has heard this information from Mr. Elton her husband, and now she was passing it to Selina. These individuals were Emma's friends hence they were expected to be happy for her, not criticize and laugh at her. Class distinctions pose serious complexities when it came to social interactions for instance, Emma does not approve Robert Martin as Harriet's suitor because of his occupation as a farmer. Austen puts across the point that gentility is not achieved merely through birthright and wealth or connections, but that it lies in one's mind through their integrity, moral conduct, wise discernment, being respectful, and being kind towards all people irrespective of their social status (Mullan, 2012 p. 300). She continues to put forward the idea that women could be independent and fulfilled without having to depend on men. This is shown when Emma has no intentions of getting married and is satisfied as a single woman. She gets agitated when Mr. Knightley proposes as the author points out that Emma was almost sinking due to the agitation of that moment. Mr. Knightley continues to say,

I cannot make speeches, Emma. If I loved you less, I might be able to talk about it more. But you know what I am. You hear nothing but truth from me. I have blamed you and lectured you, and you have borne it as no other woman in England would have borne it. Bear with the truths I would tell you now, dearest Emma, as well as you have borne the..But you understand me. Yes, you see, you understand my feelings...(Austen, 1816, 1993, p.314).

The proposal was well thought of but Emma had no interest in getting married at that point. In a society that puts importance on wealth and rank, women could break free and become gentlemen in their own right without being viewed as extensions of the property of men. For example, when in the carriage to Weston's wedding, Miss Taylor, Emma, and her father are talking when he says that he has lost some chicken to thieves and now Miss Taylor. This shows how Miss Taylor, a worker, was equated to a material property. The plights of women are further explored as Austen shows how they get depressed when they lose social status and the shame that they go through at all the tiny embarrassments that accompany their social segregation. This happened to gentlewomen such as Miss Taylor who was Emma's governess, Mrs. Goddard the mistress of Highbury school, and the Bates who were widowed and another a spinster daughter (Fowkes \& Tobin, 1988, pp. 413-430).

Emma's view of being a gentleman is much different than that of other members of the society. She views people strictly by their social classes and poses pre-judgment upon each one respectively. When the novel begins she is sure when she says that

she knows who are the chosen and the best in the village of Highbury, the second-set individuals like Miss Bates, and those beyond the pale like the farmers.(Austen, 1816, 1993, P. 190)

She refers to the Coles as low in origin as well as trade and thus they were not fully genteel. The Coles, however, get more money and rise the ranks to afford a lifestyle of the genteel class. They "employed more servants, enlarged their house, and gave dinner parties to which they invited the "regular and best families" (p. 190).

Emma viewed their rise in rank with a lot of suspicion and lack of acceptance while the other members of the genteel class like the Westons and Mr. Knightley accepted them and were more than willing to associate with them. Emma views the role of a gentleman as being considerate to the poor and engaging in charitable activities. She saw this as a duty of the people who belonged to her social class so she looked for ways that could relieve these people of their suffering. The author says that she was

compassionate: and the distresses of the poor were as sure of relief from her personal attention and kindness, her counsel and her patience, as from her purse. She understood their ways, could allow for their ignorance and their temptations, had no romantic expectations of extraordinary virtue from those for whom education had done so little, entered into their troubles with ready sympathy, and always gave her assistance with as much intelligence as goodwill (Austen, 1816, 1993, p. 94) 
Emma also believed that the people who had fallen in social ranks due to unexpected circumstances were still part of the genteel class. This is evident when she is willing to associate with the Bates and exchange gifts with them. Emma also believes that true gentility means co-existing in harmony with one's neighbors even though the parties lack a mutual understanding of one another. This is seen through the relationship that she has with her father. However, Emma failed to desire to please other people. This character trait makes the reader wonder whether this is what she perceived gentility as. She was not pleasant to Mr. Knightley in their business relationship when Mr Knightley wanted to change a route that passed through the meadows. She is for the idea but he says to his brother that "I would not attempt it if it were to be the means of inconvenience to the Highbury people" (p. 110).

Emma also viewed a gentleman as the guy who was ready and willing to give a hearty compliment to her or another woman. She judged others according to their awe of her. This is shown when she refuses to grow fond of her brother in law because he looked at her "without praise and without blindness" (p. 99). She is, however, pleased with Mr. Frank because of how he treated Mrs. Weston as shown by the author's words,

It was not merely in fine words or hyperbolic compliment that he paid his duty; nothing could be more proper or pleasing than his whole manner to her-nothing could more agreeably denote his wish of considering her as a friend and securing her affection (Austen, 1816, 1993, p.181)

At the end of the novel, Emma acknowledges that she viewed the position of a gentleman in a wrong perspective and that she is willing to change when she says that she was wrong in pairing people up. She says, "It was foolish, it was wrong, to take so active a part in bringing two people together" (p. 134) She notes that she is willing to change and writes some resolutions including engaging more in reading and her passion for drawing art. This marks her point of maturity from the little-disillusioned girl to a realistic woman of character.

Mr. Knightley has different views on what it takes for a person to be a true gentleman. He was humble and modest considering the vast amount of the property that he owned. The author says that he had inherited Donwell Abbey estate, a large family fortune that his family had possessed. He was the eldest son of his family, and his brother had moved to London to make some wealth for himself. The author says that "It was a sweet view - sweet to the eye and the mind. English verdure, English culture, English comfort, seen under a sun bright, without being oppressive." (p. 70) He prioritizes behavior and manners when learning about any individual. He detects delusions easily among the other members of the society and corrects it immediately. Thus, he is at the forefront in correcting Emma and becomes her role model when she desires to change. He also notes that Mr. Elton is not behaving in a way a true gentleman should when he seeks a bride with money. Thus he cautions Emma against matching Elton with Harriet because she will end up being disappointed. He tells her that she will have done harm to herself than good to other people as she continues to meddle in their affairs adding that she was filling Harriet's mind with delusion. Mr. Knightley views Mr. Martin as a member of gentility despite his occupation as a farmer. He warms Emma against persuading Miss Harriet not to be married by Mr. Robert Martin who is of a lower social status. This is illustrated in chapter eight whereby Mr. Robert is rejected by Emma but accepted by Mr. Knightley. He also suspects Mr. Frank's motives and later realizes that there is something that's not right between Mr. Frank and Miss Jane Fairfax. As a true gentleman, Mr. Knightley was not afraid to correct Miss Emma. Emma admires him and states "Mr. Knightley's air is so remarkably good that it is not fair to compare Mr. Martin with him. You might not see one in a hundred with a gentleman so plainly written as in Mr. Knightley." (p. 153) Mr. Knightley also is free of exaggeration. He never flatters Emma because he understands that she is delusional and thus does not wish to take part in that fantasy.

Despite the fact that many members of that society keep giving Emma praises, he does not get influenced to do so because he knows it is not the truth. He takes steps to encourage her to change, and when she makes resolutions to change, he notes that she had a list of books she wanted to read but lacked the drive to do so, "I have seen a great many lists of her drawing up at various times that she meant to read regularly through" (p. 98) Emma also enjoyed painting but she adds touches of beauty that are not present in reality. Thus, Knightley corrects her by pointing out that she had painted Harriet too tall the very opposite of what Mr. Elton had commented that it was a perfect resemblance of Harriet and no one could draw as nice as she did, "I do not know anyone who draws so well as you do," Mr. Knightley also maintains grace at all times and he expects that all gentlemen should behave similarly. When Emma hurts the feelings of Miss Bates, he quickly tells her that what she had done was wrong and she lacked grace. He says to her, "How could you so unfeeling to Miss Bates? How could you be so insolent in your wit to a woman of her character, age, and station?" (p. 190) He also portrays true gentlemanly behavior by partaking in acts of kindness and not boasting about it. He is also calm because he never seeks to be witty, the center of attention, or a big entertainer. He, however, manages to remain social by talking to all people whether genteel or those of a lower class and talks about many topics without insinuating his 
superiority. He offers transport to the Bates whenever they need it so that they cannot feel the pain of their lowered social status. He also visits Emma's father and tolerates his boring conversations about the weather and health.

Mr. Knightley's view on being a gentleman is a person of integrity at all times. He placed himself the custodian of genteel manners and is opposed to people that do not live up to these standards. While talking to Emma, he discusses the matter about Frank refusal to visit his father and seems very upset about it. He says,

There is one thing, Emma, which a man can always do if he chooses, and that is his duty; not by maneuvering and finessing, but by rigor and resolution. (Austen, 1816, 1993, p.100)

He also reprimands Frank when he flirts with other women because he is engaged, saying

So unlike what a man should be! - none of that upright integrity, that strict adherence to truth and principle, that disdain of trick and littleness, which a man should display in every transaction of his life. (Austen, 1816, 1993, p. 203)

He also enjoys chivalry as seen when he dances with Harriet to save her from the embarrassment of being rejected by Mr. Elton. He attends all functions that are required of him despite there being a possibility that he will not always enjoy the company. The author notes that he adjusted his mannerisms to please people, for example,

Mr. Elton must compose his joyous looks, and Mr. John Knightley disperses his ill-humor. Mr. Elton must smile less, and Mr. John Knightley more, to fit them for the place. Emma only might be as nature prompted, and show herself just as happy as she was. To her, it was real enjoyment to be with the Westons. (Austen, 1816, 1993, p. 118)

He portrays a different character trait from Emma who does not enjoy social visits and avoids the chatty Miss Bates opting for the laid back Jane Fairfax. He believes that a man must fulfill his duties and says, "There is one thing, Emma, which a man can always do if he chooses, and that is his duty" (p. 141) When he decides to marry Emma, he first corrects her behavior which shows that he was willing to see her change for the better. He also makes the decision to move into her home where she lives with her father. This is a big step of sacrifice because Mr. Woodhouse was a boring old man who talked about the same subject over and over again. He is willing to take this sacrifice for the sake of his relationship with Emma. The only time Mr. Knightley doubted his abilities as a gentleman was when he said.

My interference was quite as likely to do harm as to do good. It was very natural for you to say, 'What right has he to lecture me?' and I am afraid very natural for you to feel that it was done in a disagreeable manner. I do not believe I did you any good. The good was all to myself, by making you an object of the tenderest affection to me. I could not think about you so much without doting on you, faults and all, and by dint of fancying so many errors, have been in love with you ever since you were thirteen at least. (Austen, 1816, 1993, p. 394)

He felt that he was not good enough to give correction to Emma. Mr. Knightley's view of a gentleman is, therefore, evident in his character throughout the novel and he is a perfect example of true gentility.

\section{Conclusion}

From the above discussion, it is clear that the meaning of the word gentleman has changed from its original meaning. The different ages of human civilization have placed different meanings to this term to suit the needs of the lifestyle at that age. While the modern man describes a gentleman as a person of courteous behavior, the aristocracy man defined the gentry as a social class that was below the esquires and above the Yeomen. In the Victorian age, the society was seeking a change of morals. The general conduct had been ruined for trivial pleasures, so to alter human behavior, there was a shift towards the deeply religious gentleman (Gilmour, 1981, p. 238). He was soon replaced by the masculine and sports-oriented gentleman who shied away from humanities subjects. In the industrial revolution, it became increasingly difficult to identify the distinguishing factor for gentlemen. There had been intermarriages that had mixed classes. The people found it easier to penetrate the gentlemen class so that they could attain some form of recognition in the society. They, therefore, amassed wealth through trading activities and vast lands hence acquiring the title of self-made gentlemen (Greenblatt, 2012, p. 200). This phenomenon of the stratified society is put into perspective by Jane Austen's novel, Emma written in 1916. Qualitative research was helpful in gaining more knowledge about the subject matter. With the help of focus groups and individual interviews with historians, the researcher gained a lot of insight about the topic of gentility, its origins, application, and modern-day use. Through it, we indulge in a village called Highbury that encounters changing times in the way of life. We journey with the protagonist Emma as she 
embarks on self-discovery and the meaning of a true gentlewoman and gentleman. She learns how to conduct herself through the example of a man named Knightley who eventually marries her.

\section{References}

Academic Brooklyn. (2009, January). Emma:Society. Retrieved January 13, 2017, from Academic Brooklyn: http://academic.brooklyn.cuny.edu/english/melani/novel_19c/austen/ending.html

Austen, J. (1816, 1993). Emma. New York: Norton.

Cody, D. (2004, June 2). The Gentleman . Retrieved January 13, 2017, from victorianweb.org: http://www.victorianweb.org/history/Gentleman.html

Dickens, C. (1989). Great Expectations in A Treasury of Charles Dickens. London: Spring Books.

Essays. (2016, 12). Critical Evaluation of Jane Austen's Emma. Retrieved January 13, 2017, from Enotes: https://www.enotes.com/topics/emma/critical-essays/critical-evaluation

Fowkes, M.-E., \& Tobin. (1988). Aiding Impoverished Gentlewomen: Power and Class in Emma. cambridge: Cambridge University Press.

Gilmour, R. (1981). The Idea of the Gentleman in the Victorian Novel. London: George Allen \& Unwin.

Girouard, M. (1981). The return to Camelot: Chivalry and the English Gentleman. Engand: Yale University Press.

Greenblatt, S. (2012). Introduction "The Victorian Age". The Norton Anthology of British Literature. New York: Norton.

Keen, M. (2002). The origins of the English gentleman : heraldy, chivalry and gentility in medival England, c. 1300-c.1500. Tempus: Brimscombe Port.

Kirkland, T., \& Thompson, D. (1999). Darlington International Raceway, 1950-1967. Winsconstin: Osceola.

Losey, J., \& Brewe, W. D. (2000). Mapping Male Sexuality: 19th Century England. New York: Fairleigh Dickinson University Press.

McMaster, J., \& Copeland, E. (1997). The Cambridge. Cambridge: Cambridge University Press.

Mullan, J. (2012). Discovering Literature: Romantics and Victorians Status, rank and class in Jane Austen's novels. Retrieved January 13, 2017, from British Library Trust: https://www.bl.uk/romantics-and-victorians/articles/status-rank-and-class-in-jane-austens-novels

Mullan, J. (2012). What Matters in Jane Austen? Oxford: Oxford English Press.

Norton. (1993). The Norton Anthology, English Literature. London: W Norton \& Company, Inc.

Rubinstein. (1993). Edication, the 'gemtleman' and British entrepreneurship 1750-1990. Capitalism, culture and decline in Britain , 102-139.

Ruskin, J., \& Crowell, T. Y. (1910). The Complete Works of John Ruskin. London: London press.

Scott, S. W. (1998). Waverley: Or, 'Tis Sixty Years Since 1862. London: Yale University Press.

Silverman, D. (2013). Doing Qualitative Research: A Practical Handbook. Los Angeles: Sage Publications

\section{Copyrights}

Copyright for this article is retained by the author(s), with first publication rights granted to the journal.

This is an open-access article distributed under the terms and conditions of the Creative Commons Attribution license (http://creativecommons.org/licenses/by/4.0/). 